\title{
Disaggregating the dependent variable in policy feedback research: an analysis of the EU Emissions Trading System
}

\author{
Brendan Moore $^{1}$ (D) Andrew Jordan ${ }^{1}$
}

Published online: 19 March 2020

(c) The Author(s) 2020

\begin{abstract}
The literature on policy dynamics has long argued for a better conceptualization and measurement of the dependent variable ("policy"), but this fundamental point has often been neglected in the policy feedback literature. In this paper, we explore how far disaggregating policy into different elements (policy instruments, objectives, and settings) addresses this gap. We do so by examining the world's largest market-based climate policy instrumentemissions trading in the European Union-and reveal a number of valuable new insights. First, even if positive policy feedback locks in a policy instrument, actor contestation does not disappear, but narrows down to the more detailed level of policy settings. Second, feedback may operate differently at each policy level: the policy instrument and its settings may strengthen at the same time as support for broader objectives weakens. Finally, positive feedback may simultaneously strengthen opposing actors' support for multiple policy elements, leading to a form of "policy stability by stalemate." These findings highlight the need for a new, interdisciplinary phase of policy feedback research that more fully disaggregates the dependent variable across a wider range of policy areas and policy instrument types. Policy scientists are well equipped to contribute to and benefit from such a debate.
\end{abstract}

Keywords Policy feedback · Dependent variable $\cdot$ European Union · Climate change · Emissions trading

\section{Introduction}

The policy feedback literature has made important empirical and theoretical advances in recent years, building on Schattschneider's observation that "new policies create a new politics" (1935, p. 288). In general terms, this literature has studied how public policies, once adopted, influence subsequent policy making through their effects on the resources and interpretations of policy actors. Empirically, it originally focused on social policy in the USA (Campbell 2003; Pierson 1994; Skocpol 1992), but has since expanded in geographical scope (e.g., to the European Union; Daugbjerg 2003; Jordan and Matt 2014) and has analyzed other policy areas such as climate change (Skjærseth 2018; Jordan and Moore

Brendan Moore

brendan.moore@uea.ac.uk

1 Tyndall Centre for Climate Change Research, University of East Anglia, Norwich NR4 7TJ, UK 
2020), transport (Skogstad 2017), and prisons (Dagan and Teles 2015). In this context, the literature has focused on feedback effects on mass publics (e.g., Campbell 2012; Mettler and SoRelle 2014), and interest groups (e.g., Jordan and Matt 2014).

In doing so, policy feedback scholars have made a number of important theoretical contributions. First, research has further explicated the precise mechanisms through which policy feedback operates, e.g., via resource redistribution or by influencing actor interpretations of a policy (see Béland 2010; Jacobs and Weaver 2015; Pierson 1993). Second, it has distinguished between positive feedback (that strengthens a policy) and negative feedback (that weakens it) and explored the conditions under which each is more or less likely (Jacobs and Weaver 2015; Oberlander and Weaver 2015; Pierson 2004; Weaver 2010). More recently, there has been a renewed interest in the role of agency (Koreh et al. 2019; Sewerin et al. 2020), related to the role that actors play in the social construction of feedback (Dagan and Teles 2015; Oberlander and Weaver 2015, p. 58) and its intentional creation (Jordan and Matt 2014, p. 233; Jordan and Moore 2020; Haelg et al. 2020).

In this article, we focus on a key gap in the existing literature: the nature of the dependent variable, i.e., "policy." In the past, many scholars have focused on policy feedback mechanisms, i.e., how "policy creates a new politics" (Jacobs and Weaver 2015, pp. 444-450; Pierson 1993, p. 626; Skocpol 1992, p. 58). In addition, others have examined policy as an independent variable, focusing on how feedback effects are created by specific policy design elements, such as the level of pension benefits (Campbell 2011) or the inclusion of policy revision provisions (Jordan and Matt 2014, pp. 233-234). However, the existing literature still leaves relatively unspecified the policy aspects which are actually impacted by feedback effects, either treating policy as a single, aggregated whole or neglecting the issue entirely. Analyzing policy feedback at a broad level has, as noted above, proven fruitful, but struggles to capture instances where feedback has distinct impacts on different policy design elements (Hacker 1998; Jacobs and Weaver 2015).

To address this gap, we draw on the policy change literature to develop an approach that distinguishes between the impacts of policy feedback on different policy sub-elementsinstruments, objectives, and settings (Cashore and Howlett 2007; Daugbjerg 1997; Hall 1993; Howlett and Cashore 2009). Our research question is as follows: through what mechanisms and with what net effects does a particular policy instrument produce feedbacks at the level of policy instruments, objectives, and settings? In doing so, we analyze the case of the European Union Emissions Trading System (EU ETS), a key climate and energy policy in Europe. The EU ETS is the world's largest greenhouse gas emissions trading system (Point Carbon 2018, p. 3) and has a long policy history, dating back to the late 1990s. During that time, it has undergone a near-continuous process of policy change: since 2003, six major reforms have been adopted (Jevnaker and Wettestad 2017; Skjærseth and Wettestad 2010). The ETS is a highly complex instrument that creates uneven benefits and costs for a wide range of actors. It is also a prominent example of a market-based instrument in the climate policy field, and a key component of EU policy in this area. As a result, it offers a promising case in which to assess the usefulness of adopting a more disaggregated view of the dependent variable which could potentially be generalized and tested in relation to other policy instruments. Thus, for us analyzing the ETS is a first step in outlining a more disaggregated approach to studying policy feedback and testing its applicability in an actual case of policy change (Eckstein 1975).

To inform our test, we utilize process tracing (Bennett and Checkel 2015, p. 7). Our main sources of evidence are primary and secondary documents including official publications of the European Union institutions, other policy documents, position papers by non-governmental actors, news media reports and reports by research institutes and think 
tanks. In addition, we draw on thirty-two semi-structured elite interviews with European Commission officials, Members of the European Parliament and staff, government officials in the Environment Council, as well as staff in environmental NGOs and business associations.

The rest of this article proceeds as follows. The next section situates our argument in the existing literature on policy feedback, noting the different mechanisms and directions through which feedback operates. The subsequent section presents our more differentiated approach to "policy," distinguishing between the impact of policy feedback on policy objectives, instruments, and settings. We then analyze the EU ETS over a 20-year time period from 1998 to 2018, thus easily satisfying the widely recognized minimum standard in policy research (Jenkins-Smith et al. 2014, pp. 192-193). Finally, we discuss our main findings and, in the concluding section, identify promising new directions for policy feedback research.

\section{Policy feedback: an overview}

Policy feedback is the process through which a public policy affects actors (e.g., by creating new resource flows or costs), and in turn influences subsequent policy making in ways that may eventually lead to changes in the original policy. In reviewing the existing literature on this concept, we will focus on three core aspects: feedback mechanisms; the distinction between positive and negative feedback; and existing approaches to disaggregating the dependent variable. For us, policy feedback is self-evidently not the only factor that can affect policy change; multiple other factors may also be crucial. We do not attempt to test policy feedback as an explanatory factor to the exclusion of these other potential factors (as others have attempted to do, e.g., Pierson 1994). Instead, other factors are conceptualized as interacting with feedback mechanisms to lead to observed policy outcomes.

Scholars have categorized the mechanisms of policy feedback in a number of ways (e.g., Jacobs and Weaver 2015, p. 445; Oberlander and Weaver 2015, pp. 41-42; Skocpol 1992, p. 58). Especially influential has been Pierson's (1993, p. 626) division between resource/ incentive and interpretive mechanisms. Resource/incentive mechanisms operate through the effects that a policy has on the resource flows and incentives which confront political actors. Examples include policy-induced changes to the level of resources that actors have at their disposal (Campbell 2003; Pierson 1993, pp. 598, 626), an actor's capacity to influence future policy-making processes (Mettler 2002, p. 353), or the incentives for political action (Pierson 2000). Interpretive mechanisms operate through the effects that a policy has on actors' interpretations, both of the policy itself and the wider issue area. For example, the way in which a policy is designed can influence its own visibility to its target groups, making it easier or more difficult for actors to understand how it has affected them (Pierson 1993, 1994).

It has long been recognized that policy feedback can strengthen a policy through positive feedback or weaken it through negative feedback (for an early example, see Skocpol 1992, pp. 58-59). The literature has largely focused on positive policy feedback (e.g., Campbell 2003; Pierson 1994, 2000). However, following an influential intervention by Weaver (2010), there has been a stronger focus on negative feedback and its role in weakening policies. A number of studies have also looked at the interaction between positive and negative feedbacks (e.g., Béland et al. 2018; Jacobs and Weaver 2015; Jordan and Matt 2014; Meckling 2019; Oberlander and Weaver 2015; Skogstad 2017). 
Ideally, an expanded focus on both positive and negative feedbacks should lead to a more in-depth discussion of which policy aspects are being strengthened or weakened by policy feedback. But the existing literature has largely chosen to adopt a highly blunt, i.e., aggregated, definition of policy, defined variously as an individual policy instrument (e.g., Jordan and Matt 2014), a policy mix (Skjærseth 2018), a piece of legislation (Béland et al. 2018), or a policy regime (Weaver 2010). However, some scholars have begun to explore how policy feedback can have distinct effects on the constituent elements of an overall policy. This approach was apparent in Oberlander and Weaver's (2015, p. 47) account of the U.S. Affordable Care Act, in which they discussed how the legislation's "broad array of policies" were affected by feedback. More recently, Béland et al. (2018, p. 2) have argued for "breaking down the [Act] into some of its different policy components" (see also Béland et al. 2020).

We believe these efforts have the potential to shed new light on policy dynamics in general and policy feedback in particular for two reasons. First, the sheer size and complexity of some public policies makes it more likely that they will create multiple feedbacks, both positive and negative, and that these will affect different elements of the same policy in distinct ways. This pattern can certainly be seen with respect to the Affordable Care Act, where positive feedback related to popular provisions, such as the regulations requiring health insurance companies to cover pre-existing medical conditions, stood in contrast to negative feedback related to unpopular provisions that imposed costs on the public, such as the financial penalty for failing to purchase health insurance (Béland et al. 2018, pp. 21-23; Oberlander and Weaver 2015, p. 58).

Second, policy feedback may have different impacts on a policy instrument and its ability to fulfill its objectives. Scholars have long included both of these elements in their definitions of policy feedback in a way that implies that feedback that strengthens an instrument will also support the fulfillment of its objectives. In her influential contribution, Skocpol (1992, p. 60) states that positive policy feedback occurs if a policy "stimulates groups and political alliances to defend the policy's continuation and expansion," while negative feedback stimulates "groups that seek to repeal or reorient the policy in question" (emphasis added). But in the same section (p. 59), she adds that feedback can also serve to "promote [...] the further extension of [a] line of policymaking" or "frustrate the further extension of that line of policymaking" (p. 59, emphasis added). Hers is thus a wider definition of feedback, potentially encompassing both the policy itself and its long-term objectives. Similar definitions can be found in more recent work. Jacobs and Weaver (2015, p. 444) state that positive feedback serves to "reinforce the underlying social foundations of [a policy's] own political support," in contrast to negative feedback that serves to "diminish those policies' bases of political support."1 But they also argue that feedback can either "strengthen the direction and orientation of status quo policy" or "result in changes that run against the grain of current policy" (emphasis added).

And indeed in some cases, when positive feedback strengthens a policy instrument it also makes successful policy outcomes more likely, and vice versa. For example, positive feedback that strengthened the position of public pensions in the U.S. also helped to advance the ultimate objective of supporting the elderly (Campbell 2003). But the policy feedback literature has also noted cases where a policy instrument's political success is detrimental to its ultimate objectives. For example, policies designed to support the use of

\footnotetext{
1 Jacobs and Weaver refer to positive feedback as "self-reinforcing feedback" and negative feedback as "self-undermining feedback."
} 
corn-based ethanol as a transport fuel have built strong supportive constituencies among farmers and have proven politically resilient, despite their dubious environmental credentials (Biber et al. 2017, p. 670; see also Skogstad 2017).

On the other hand, negative policy feedback can also contribute to the removal of an ineffective policy instrument and its replacement by an alternative. In the EU, this was the pattern of change in the area of car emissions (Jordan and Matt 2014). The initial emission reduction policy, a voluntary agreement to reduce carbon dioxide emissions brokered between the European Commission (the EU's executive body) and the automobile industry, was so weak that it was widely perceived to have failed, empowering the coalition that had long advocated for regulatory instruments (Jordan and Moore 2020). We believe that a more disaggregated approach to policy feedback can better capture these complex dynamics which are a potentially important aspect of policy change, and turn to that topic in the next section.

\section{Disaggregating policy into its constituent elements}

Our approach to disaggregating policy draws on and makes fresh connections between the literatures on policy change, policy dynamics, and social learning. A useful starting point is Hall's (1993) landmark study of economic policy, in which he identified three policy "variables" or elements: "the overarching goals that guide policy in a particular field, the techniques or policy instruments used to attain those goals, and the precise settings of these instruments" (Hall 1993, pp. 278-279, emphasis added). He defined goals as the broad outcome sought by a policy, instruments as the specific tools used to attain those goals, and instrument settings as the more operational decisions about, e.g., the level of funding associated with a subsidy. A number of scholars have used Hall's framework as the basis for modified approaches to understanding policy change. For example, Daugbjerg (1997, pp. 126-127) added the concept of policy principles (e.g., market principles versus the principle of state intervention in agricultural policy).

More recent theoretical work has sought to further expand on Hall's original approach. For example, Cashore and Howlett (2007) distinguished the difference between policy ends and policy means, as well as between levels of abstraction: specific on-the-ground measures, program-level operationalization, and high level abstraction (Howlett and Cashore 2009). This leads to six policy elements. At the highest level of abstraction are broad goals (e.g., environmental protection) and instrument logics that guide which types of policies are used. Program-level operationalization includes formal policy objectives as well as policy instruments. Finally, on-the-ground measures include policy settings and their calibrations/levels. This taxonomy of policy components has been used in a number of studies of comparative policy analysis (e.g., Burns et al. 2018; Dupuis and Biesbroek 2013; Schaffrin et al. 2015). The terminology employed by Hall, Daugbjerg, and Cashore/Howlett at times overlaps, but their definitions are not always aligned. For example, Daugbjerg's concept of policy principles shares aspects with Howlett and Cashore's concept of instrumental logic, whereas Hall's notion of settings seem to be closer in meaning to Howlett and Cashore's calibrations (see Howlett and Cashore 2009, p. 36).

For simplicity's sake, our approach focuses on three main elements: policy instruments, objectives, and settings. It relies mainly on Hall's approach but shares some similarities with the taxonomies of Daugbjerg and Cashore/Howlett. First, sitting at the center of the analysis is the policy instrument being analyzed. Policy instruments - the tools of 
government-can be classified in several ways. One approach is to compare instruments according to their level of coerciveness, from low-coerciveness voluntary instruments to mandatory, high-coerciveness regulatory instruments (Phidd and Doern 1992). Another important distinction is between substantive instruments, which are aimed at addressing the specific policy issue at hand, and procedural instruments focused on coordinating policy formulation, decision-making, and implementation (see Capano and Howlett 2020). In general, positive policy feedback increases the likelihood that the status quo instrument will remain stable, whereas negative feedback lowers it. Within the policy instrument category, we also distinguish between specific policy instrument components, i.e., individual design elements within an instrument, such as the cap in a cap-and-trade system (Béland et al. 2018).

Second, policy objectives can either be codified in legislation or be part of the tacit knowledge that unites policy actors into coalitions. Objectives and their relative importance can be contested by different actors, especially in cases where a policy instrument aims to reach multiple objectives at the same time, perhaps involving difficult tradeoffs (see Ackrill and Kay 2014). Positive policy feedback affecting policy objectives creates a higher likelihood of achieving or exceeding those objectives, while negative feedback creates a lower likelihood of this happening.

Third, policy settings include the level of funding provided for by a subsidy instrument, the strictness of emission limits in an environmental pollution regulation, or the generosity of the benefit provided by a public pension instrument. Positive policy feedback affecting a policy setting creates a higher likelihood of more stringent or stable policy settings. Negative feedback creates a higher likelihood of less stringent settings. In reality (and depending on its complexity), a policy instrument is likely to have a large number of settings which can generate political contestation during the formulation process. As a result, policy feedback that strengthens one policy setting may simultaneously weaken others, especially if two settings are mutually exclusive or involve a tradeoff. Table 1 sets out each of the policy elements introduced above and their relationship to positive and negative policy feedback (see also Haelg et al., this issue; Daugbjerg and Kay, this issue).

\section{The EU Emissions Trading System}

\section{Core design features}

The EU ETS is an example of a cap-and-trade system, which sets a limit on the amount of greenhouse gases that can be emitted in covered sectors, then allocates tradable "emission allowances" to these sectors (Tietenberg 2006). The industries concerned are required to surrender allowances equal to their emissions. Allowances are either distributed for free to specific recipients (free allocation) or auctioned to the highest bidder. The ability to trade allowances provides organizations (normally companies) with the option to either reduce emissions or buy allowances. The ETS has had four phases: Phase I (2005-2007), Phase II (2008-2012), Phase III (2013-2020) and Phase IV (2021-2030).

Under the EU's Ordinary Legislative Procedure, the European Commission coordinates ETS-related policy formulation and publishes initial legislative proposals. Proposals are then adopted jointly by the directly elected European Parliament and the Environment Council, where environment ministers from the national governments of the EU member states meet. The European Council, consisting of the Heads of State and Government of 


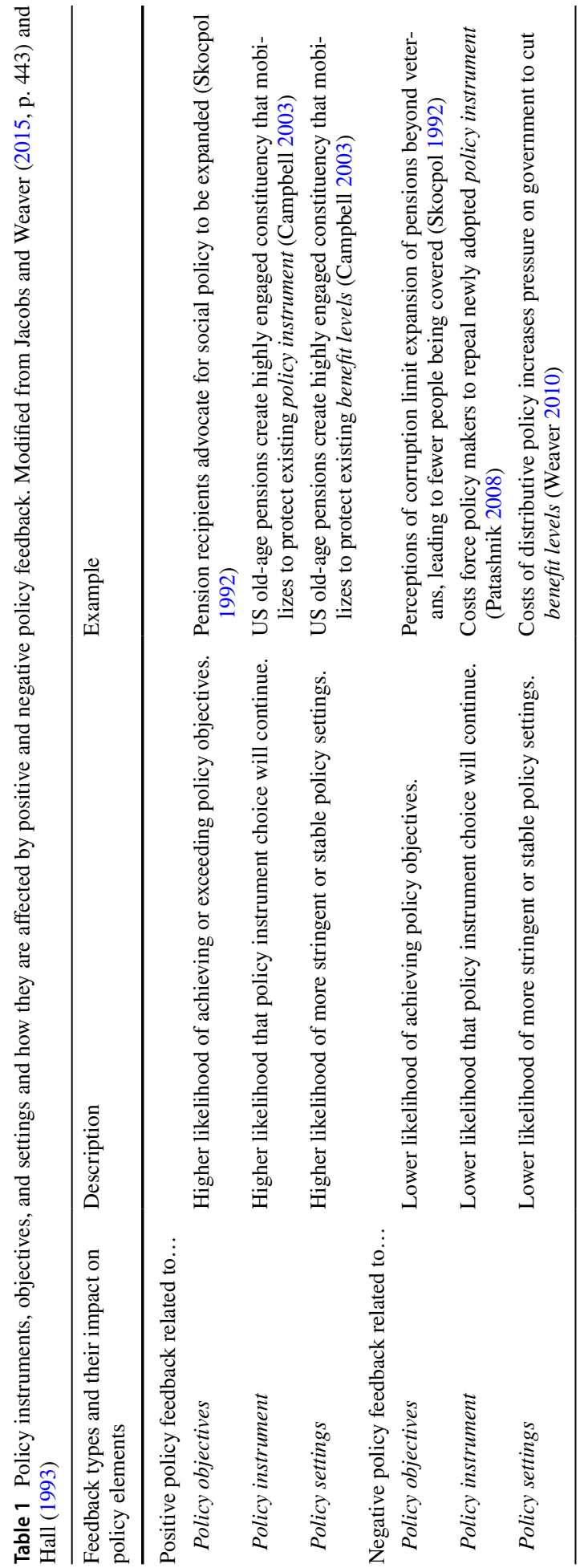


the member states, sets the EU's overall policy direction. The key industries covered by the ETS (the target groups) are the electricity generation industry and the so-called energyintensive industries (including steel, cement, refineries, glass, and paper production) ${ }^{2}$ Outside of these industries, a large number of market intermediaries (such as financial institutions, banks, and energy traders), as well as environmental NGOs (ENGOs), are also strongly engaged in ETS-related policy making and thus have the potential to be affected by policy feedback.

\section{Policy adoption (1998-2003)}

EU emissions trading was first proposed after the EU failed to adopt a carbon/energy tax in the early 1990s (Skjærseth and Wettestad 2008, pp. 1-6). Before the ETS was adopted in 2003, support was mixed for emissions trading. The European Commission's 2001 legislative proposal called for a mandatory, EU-wide cap-and-trade system (European Commission 2001a). A number of EU member states supported emissions trading in principle. However, even some supporters such as the UK pushed for a voluntary system (European Commission 2001b, pp. 8-9). In the Council, the German government was skeptical and considered blocking the proposal (Skjærseth and Wettestad 2008, pp. 108-110). The European Parliament was generally supportive of the approach (European Commission 2001b, p. 2). ${ }^{3}$

Environmental NGOs, coordinated by Climate Action Network Europe (CAN Europe), emphasized that the ETS was only a small part of the solution and needed to be designed rigorously (European Commission 2001b, p. 5). While many electricity companies and oil companies supported emissions trading (Eurelectric 2001; Meckling 2011), most of the energy-intensive industries, as well as German electricity generators, preferred voluntary, non-binding agreements between national governments and industry (European Commission 2001 b, p. 1). ${ }^{4}$ However, the energy-intensive industries were disengaged early in the process and did not effectively coordinate their positions (Wettestad 2009). ${ }^{5}$ Regardless of the mixed support for the proposal, the ETS Directive was eventually adopted unanimously by the Council and the Parliament and began operation in January 2005.

\section{Policy Centralization (2003-2009)}

Once it was in place, the ETS became a 'fact on the ground' (Müller and Slominski 2013, p. 1435). EU member states, the European Parliament, and the Commission had all invested significant political capital in adopting the measure, and it had become a major part of the EU's response to its commitments under the 1997 Kyoto Protocol. Positive resource/incentive feedback mechanisms helped push the electricity generation industry to unite in support of the instrument, in part because they were able to pass on a high proportion of their allowance costs to energy consumers (including the energy-intensive

\footnotetext{
2 Since 2012, the ETS has also covered aviation activities within the EU. However, the aviation industry, and the policy making surrounding its inclusion, is treated differently than other ETS industries. Due to space constraints, it is excluded from this analysis.

3 Interviewee, European Parliament. May 13, 2016.

4 Interviewee, Electricity Industry. April 11, 2017.

5 Interviewee, European Commission. May 20, 2016.
} 
industries) and many were able to secure additional, "windfall" profits in this way (Sijm et al. 2006). Other resource/incentive mechanisms strongly affected carbon market traders and consultants, who became much more supportive and engaged in policy making as the value of the allowance market increased. ${ }^{6}$ Influenced by positive interpretive mechanisms, CAN Europe became more supportive as the ETS grew in importance and shifted closer to their design preferences of a centralized system (Moore 2018, p. 146; Skjærseth and Wettestad 2010, pp. 111-112).

The broadening of support for the instrument did not, however, mean that political opposition entirely disappeared. Initially, the energy-intensive industries continued to push for alternative market-based approaches to the cap-and-trade instrument (Alliance of Energy Intensive Industries et al. 2007). But they also received new financial resources through free allocation of allowances (which they benefited from disproportionately) and gradually moved to advocating change within the logic of the cap-and-trade system. They also realized that they had shared interests in continued free allocation and formally created the Alliance of Energy Intensive Industries (AEII) in 2005 to lobby on ETS-related issues (AEII 2005).

While the ETS as a policy instrument now seemed more secure, it underwent major changes after 2013. The instrument adopted in 2003 was highly decentralized: each of the 27 member states allocated emission allowances to companies (under Commission oversight) and determined how many were auctioned (up to an $8 \%$ maximum over the 2005-2012 period). The overall ETS cap was determined 'bottom-up' by combining these national allocations. In the first two trading phases, member states gave $97 \%$ of allowances to industry for free (the free-allocation share) and auctioned only $3 \%$ (the auction share). Free allocation transferred the value of allowances to ETS industries, while auctioning transferred it, as revenue, to member state governments. As a result, free allocation in the first two trading phases led to a significant transfer of resources to industry (de Bruyn et al. 2016).

The decentralized design of the ETS allowed industries to move from one member state to another to negotiate, insisting on higher allocations for themselves and claiming that their future investment decisions would be contingent on these decisions (Moore 2018, pp. 139-140; Wettestad 2009). ${ }^{7}$ This created important negative interpretive feedback mechanisms among the member states, who became highly frustrated with the national allocation process. ${ }^{8}$ Another effect of overallocation was that in the first trading phase (2005-2007) the ETS had more allowances available than emissions. This undermined the policy objective of reducing overall emissions from ETS sectors and led to a steep fall in allowance prices from $€ 30$ to near zero by 2007. Partly in response, in its oversight role the Commission cut a number of national allocations in the second trading phase (2008-2012).

While the decentralized ETS was favorable to many affected industries, it nonetheless led to growing support for a new approach among the member states, who had initially blocked the centralized system that the Commission's Directorate-General for Environment (DG Environment) and the European Parliament had long preferred. The 2009 Directivewhich reformed the ETS for its third trading period between 2013 and 2020 - therefore

\footnotetext{
${ }^{6}$ Interviewee, Market Intermediary. June 21, 2016.

7 Interviewee, Member State Government. June 7, 2016; Interviewee, European Commission. July 30, 2016.

${ }^{8}$ Interviewee, European Commission. May 20, 2016; Interviewee, Member State Government. June 7, 2016.
} 
created an EU-wide cap set in accordance with the EU's commitment to a $20 \%$ greenhouse gas emission reduction by 2020 compared to 1990 levels. Starting in 2013, a linear reduction factor (LRF) automatically reduced the cap by $1.74 \%$ per year to reach a $21 \%$ reduction in ETS sectors by 2020 compared to 2005 emission levels.

The 2009 Directive centralized allowance allocation and created a major shift toward auctioning. Drawing on evidence that auctioning was both more effective and could address the problems with allocation from the first two phases (DG Environment and Ecofys 2006), the 2009 Directive increased auctioning from 3 to $57 \%$ of allocation and reduced free allocation from $97 \%$ to $43 \%$. Energy-intensive industries continued to receive free allocation at a reduced level, and most electricity generators were required to buy allowances at auction. However, the Central and Eastern European member states such as Poland successfully secured the option to allocate $40 \%$ of their auctioning allowances to their electricity generators for free (ENDS Report 2008). Crucially, two key policy instrument components-the free-allocation share and the auction share-were centralized to the EU level, giving the EU institutions more responsibility.

\section{Intervening in the market (2009-2018)}

Just as the 2009 Directive was being finalized, the ETS faced new problems caused by external factors, especially the European economic crisis that began in 2008. Sharply falling emissions and panic selling from ETS industries led to a new oversupply of allowances-which was referred to as the "allowance surplus" (Capoor and Ambrosi 2009, p. 6; European Commission 2012). This surplus increased to 2.1 billion allowances by 2012, causing prices to fall from a high of near $€ 30$ in 2008 to below $€ 5$ in 2012 (Sandbag 2019). The EU sought to address this issue with "volume management" to reduce the allowance surplus and, it was hoped, raise prices. These efforts were highly contentious, but crucially they focused on the settings and design of the ETS, not the fate of the policy instrument itself. The coalition in support of volume management was brought together by various feedback mechanisms. The Commission supported raising the price because the perceived efficacy of the ETS had become closely tied to the price level. Environmental NGOs supported higher prices as a way to drive decarbonization. A number of other actors had benefited from the resource/incentive mechanisms created by the ETS, mechanisms that grew stronger when prices were high. These actors included low-carbon electricity generators that benefited when the carbon price indirectly raised electricity prices, market intermediaries, and many of the EU member states which derived more revenue from auctioning (European Commission 2017). In contrast, energy-intensive industries and high-carbon electricity generators, already under pressure from the imminent reduction of free allocation in the 2009 Directive, argued that low prices were an appropriate response by the market-based ETS to the economic crisis and that the "carbon price [...] reflects the economic downturn exactly as it should" (AEII 2012a, p. 1). Therefore, although contestation had moved down to the detailed level of settings, policy debates were still closely tied to fundamental disagreements about the objectives of the ETS. Actors that supported volume management emphasized the ETS's role in triggering technological innovation by driving decarbonization (thus requiring higher prices), whereas the actors that opposed it emphasized the importance of aiming for cost-efficient emission reductions (and lower prices).

One approach to volume management was to increase the linear reduction factor (LRF) that progressively tightened the ETS cap, which also would have contributed to the policy's emission reduction objective (European Commission 2012). This option was supported by 
actors including most electricity generators, some member states including the UK, and environmental NGOs (European Commission 2013, p. 5). The energy-intensive industries were opposed because increasing the LRF would raise prices and reduce the amount of allowances available for free allocation. The Alliance of Energy Intensive Industries and a number of Central and Eastern European electricity generators also opposed the European Council setting a unilateral greenhouse gas target in the international negotiations leading up to the Paris Agreement in 2015 because it would also affect the LRF, thereby directly opposing stronger EU-wide targets even outside the ETS (AEII 2012b; Polish Electricity Association 2013, p. 2). In the end, the central approach taken to volume management was a delay to the auctioning of 900 million allowances (backloading, adopted in 2013) and the creation of a Market Stability Reserve (MSR, adopted in 2015). The MSR would withdrawal the equivalent of $12 \%$ of the allowances in circulation if the surplus rose above a pre-defined threshold (see Wettestad and Jevnaker 2016). Crucially, these withdrawn allowances would be taken from the auction share, in part to avoid the politically fraught process of removing them from the free allocation to individual companies. ${ }^{9}$

These debates on volume management and allocation continued during the preparation of the 2018 Directive, the legislation that set the parameters for the ETS's fourth trading period between 2021 and 2030 (see Wettestad and Jevnaker 2019). In 2014, the European Council had decided to set a 40\% reduction target for 2030 (European Council 2014), and the 2018 Directive was meant to implement that new target for the ETS. In these discussions, a coalition including France, Sweden, and the UK pushed for more changes to raise allowance prices further, including a temporarily increased $24 \%$ intake rate into the MSR and cancelation of MSR allowances. These proposals were supported by the actors that would benefit from high carbon prices, including low-carbon electricity generators and market intermediaries. Although not explicitly designed for this purpose, allowance cancellation would also indirectly increase the stringency of the ETS cap and therefore increase greenhouse gas reductions. During this time, the Alliance of Energy Intensive Industries opposed an increased MSR intake as well as cancelation, but they largely focused their time and energy on increasing the free-allocation share at the expense of the auction share (Moore 2018, p. 210). Energy-intensives generally called for there to be no limit on free allocation under the ETS's cap, implying that in principle the ETS could become $100 \%$ free allocation (see European Commission 2015, p. 113). On the other side, some actors such as the UK called for a complete phase-out of free allocation, meaning the ETS would only have an auction share afterward. There were therefore coalitions working to both increase the free-allocation share and the auction share. However, if one increased, another would need to decrease. In the end, the $24 \%$ rate for the MSR and cancelation starting in 2024 were agreed, along with an increase in the free-allocation share to $45 \%$ between 2013 and 2030, contingent on the extra allowances being needed by the energy-intensive industries.

\section{Disaggregating the dependent variable: a discussion}

In this article, we have developed and applied a new approach to disaggregating the dependent variable in policy feedback research. Drawing on Hall's (1993) seminal framework, we have differentiated between the impact of policy feedback on a policy

\footnotetext{
${ }^{9}$ Interviewee, European Commission. July 30, 2016.
} 
instrument, its objectives, and its detailed settings. Our analysis has revealed a number of important findings that would have remained hidden if we had retained an aggregated focus. In relation to the policy instrument as a whole, the policy feedback created by the ETS was strongly positive. An instrument that encountered significant opposition when it was first proposed had, within a few years, secured the political support of nearly all key policy actors, including many of those that had initially been opposed. In doing so, emissions trading became entrenched as the EU's core instrument to achieve greenhouse gas emission control from electricity generation and the energy-intensive industries. However, there was a major change in the policy's components between 2003 and 2009, with the expansion of allowance auctioning and the shift from national caps to an EU cap. This was driven in large part by dynamics triggered by the initial, more decentralized design of the ETS. Industries were able to lobby their member state governments for higher allocations, leading to widespread frustration among EU-level policy makers. At the same time, many other policy components, such as the free-allocation share and the auction share, helped to nurture constituencies that supported their continuation and expansion (Voß and Simons 2014; Simons and Voß 2018). The benefits of free allocation for energy-intensive industries led them to strongly support the maintenance and expansion of the free-allocation share. The same was true of the support that the auction share received from low-carbon electricity generators and several member states. Crucially, once adopted, the key components of the revised ETS — namely the EU-level cap and the linear reduction factor-were not seriously challenged.

The entrenchment of the ETS and its major policy components after 2009 led to a narrowing down in the scope of political contestation to focus largely on the policy's detailed settings. The dividing line between auctioning and free allocation, a seemingly technical design issue that arose at the beginning of the ETS, became politically more and more consequential, with fierce debates breaking out between opposing coalitions. The same was true of the linear reduction factor-another highly specific design feature that provided an automatic means of adjusting the system's settings. When new components were added to the ETS - most importantly the Market Stability Reserve-they too became foci of political contestation. Policy, in other words, seemed to restructure politics in the manner predicted by policy feedback theory.

Meanwhile, a new tension was also created between policy feedbacks related to settings and those related to objectives. Free allocation in the first two phases (2005-2012) was a key concession made by the European Commission to guarantee the instrument's adoption. But reducing emissions more quickly also withdrew resources from politically influential groups-namely the energy-intensive industries and the Central and Eastern European electricity generators-who quickly responded. In turn, they opposed further increases in the ambition level of the EU's broader greenhouse gas reduction objectives because they would lead to a tighter ETS cap. In contrast, dissatisfaction with low allowance prices undermined actors' support for status quo policy settings, such as the linear reduction factor, but reinforced support for moving closer to policy objectives and rarely led actors to question the policy instrument itself. For example, negative feedback related to the new settings introduced by the 2009 Directive was a pre-condition for the increased emission reductions caused by the combination of backloading, the MSR, and the 2018 Directive.

To summarize, disaggregating policy into its component parts sheds light on the multiple ways in which policy feeds into politics and then back into policy. In fact, the ETS created multiple feedbacks which, in turn, affected many different elements of the original policy at the same time. The multiple directions of feedback would not have been 
apparent if we had only investigated positive feedbacks. The feedbacks related to different policy elements would not have been visible if we had treated the ETS as a single aggregated policy.

Our case has also revealed three novel findings of a more general nature. First, Béland et al. (2018, p. 22) have argued that in the context of the US Affordable Care Act, "because major reforms are interdependent webs of regulatory and fiscal authority, unpopular provisions may not be easily replaced without undercutting popular reforms." In other words, policy components that are subject to negative feedbacks may be difficult to dismantle because they are inextricably intertwined with other, more popular provisions that are supported by positive feedbacks. Our case raises a rather different possibility: critical policy components, namely the linear reduction factor, the auction share, and the free-allocation share, each generated constituencies which actively supported their expansion. However, increasing the reduction factor decreased the total size of the allocation available for auctioning and free allocation. Similarly, increasing the auction share required reductions in the free-allocation share (and vice versa). As a result, support for strengthening one of these components necessitated weakening the other two, leading to a situation of relative "policy stability by stalemate" after 2009, wherein a change in any of the three components elicited strong political opposition.

Secondly, the initial complexity of the ETS, itself the result of an uneasy compromise between policy actors with widely diverging preferences, created multiple, overlapping positive and negative policy feedbacks. For example, when allowance prices fell after 2008, it was difficult to increase the linear reduction factor to raise prices because of resistance from actors that feared they would be harmed, such as Central and Eastern European electricity generators. As a result, policy makers were forced to resort to an even more complex form of volume management, first delaying auctioning through backloading, then creating the Market Stability Reserve, and finally modifying the MSR to create a system for canceling allowances. At each step in this protracted process, new instrument interventions led to new policy feedbacks which interacted with the already existing ETS. Therefore, a key pattern we have revealed is that instrument complexity begets fresh complexity, in terms of both the policy's design and its evolving feedback dynamics.

Finally, our case highlights the importance of agency in the operation of policy feedback. With finite resources to commit to lobbying, actors faced difficult choices over how to respond to multiple, sometimes contradictory policy feedbacks. For example, during the negotiation of the 2018 Directive, the Alliance of Energy Intensive Industries pushed for an increase in the free-allocation share while also opposing further volumemanagement provisions such as canceling allowances. The Alliance eventually chose to focus on free allocation - a choice that made it more likely that the volume-management provisions would be successfully adopted. Our broader point, however, is that while policy feedback may make certain pathways more or less likely, the final outcome often depends on how feedback is interpreted and used as a resource by policy actors (Dagan and Teles 2015). 


\section{Conclusion and new research directions}

We have demonstrated that a more disaggregated approach to the dependent variable provides a richer understanding of policy feedback. Our findings highlight the need for a new phase of policy feedback research that more fully disaggregates the dependent variable across a wider range of policy and instrument types (e.g., analyzing both substantive and procedural instruments), as well as in increasingly complex policy mixes. Such analyses would allow scholars to explore when it is more appropriate to focus on policy as a single dependent variable (e.g., when policies are less complex or where a policy and its objectives are expected to be aligned) and when it may be advisable to adopt a more disaggregated approach (e.g., when analyzing internally complex policies in which policy instruments and objectives are more likely to be in tension). Future research could also explore other approaches to disaggregating the dependent variable. For example, the taxonomy developed by Cashore and Howlett (2007) could be employed to analyze the role of policy feedback in the development of abstract policy goals (such as environmental protection versus economic development) or the instrument logics that guide policy actors' preferences for one type of instrument over another (Cashore and Howlett 2007, p. 536). Disaggregated analyses will admittedly require more resources and time on the part of researchers. This should be balanced against the analytical benefits of such an approach (Béland et al., this issue; Haelg et al., this issue; Daugbjerg and Kay, this issue).

To conclude, the proliferation of new work on the mechanisms, directions, and effects of policy feedback is welcome (for reviews, see Béland 2010; Béland and Schlager 2019; Campbell 2012; Jordan and Matt 2014; Mettler and SoRelle 2014). A more active consideration of the dependent variable in this research should, we think, be a priority. While "there is simply no such thing as the ultimate solution" to the configuration and measurement of policy (Green-Pedersen 2004, p. 12), our analysis nonetheless suggests that a disaggregated approach will allow policy scientists to engage in a broader, more interdisciplinary debate on the role of policy feedback.

Acknowledgements The authors thank the Centre for Climate Change and Social Transformations (ESRC ES/S012257/1) for funding. Brendan Moore thanks the School of Environmental Sciences at the University of East Anglia for funding through a PhD studentship and the COST network INOGOV-Innovations in Climate Governance (IS1309) for supporting fieldwork and interviews via a Short-Term Scientific Mission.

Open Access This article is licensed under a Creative Commons Attribution 4.0 International License, which permits use, sharing, adaptation, distribution and reproduction in any medium or format, as long as you give appropriate credit to the original author(s) and the source, provide a link to the Creative Commons licence, and indicate if changes were made. The images or other third party material in this article are included in the article's Creative Commons licence, unless indicated otherwise in a credit line to the material. If material is not included in the article's Creative Commons licence and your intended use is not permitted by statutory regulation or exceeds the permitted use, you will need to obtain permission directly from the copyright holder. To view a copy of this licence, visit http://creativecommons.org/licenses/by/4.0/.

\section{References}

Ackrill, R., \& Kay, A. (2014). The growth of biofuels in the 21st century: Policy drivers and market challenges. London: Palgrave MacMillan.

Alliance of Energy Intensive Industries (2005). The impact of EU emission trading scheme (ETS) on power prices. Brussels: AEII. 
Alliance of Energy Intensive Industries (2012a). Position of the alliance of energy intensive industries on the commission proposal to back-load (set-aside) EU ETS allowances. Brussels: AEII.

Alliance of Energy Intensive Industries (2012b). 7 March 2012: Statement of the European alliance of energy intensive industries. Brussels: AEII.

Alliance of Energy Intensive Industries, Cefic, \& International Federation of Industrial Energy Consumers (2007). Contribution paper for the EU ETS review. Brussels: AEII, Cefic \& IFIEC.

Béland, D. (2010). Reconsidering policy feedback: How policies affect politics. Administration and Society, 42(5), 568-590.

Béland, D., \& Schlager, E. (2019). Varieties of policy feedback research: Looking backward, moving forward. Policy Studies Journal, 47(2), 184-205.

Béland, D., Howlett, M., Rocco, P., \& Waddan, A. (2020). Designing policy resilience: Lessons from the Affordable Care Act. Policy Sciences.

Béland, D., Rocco, P., \& Waddan, A. (2018). Policy feedback and the politics of the Affordable Care Act. Policy Studies Journal, 47(2), 395-422.

Bennett, A., \& Checkel, J. T. (2015). Process tracing. In A. Bennett \& J. T. Checkel (Eds.), Process tracing: From metaphor to analytic tool. Cambridge: Cambridge University Press.

Biber, E., Kelsey, N., \& Meckling, J. (2017). The political economy of decarbonization: A research agenda. Brooklyn Law Review, 82(2), 605-643.

Burns, C., Tobin, P., \& Sewerin, S. (Eds.). (2018). The impact of the economic crisis on European environmental policy. Oxford: Oxford University Press.

Campbell, A. L. (2003). How policies make citizens: Senior political activism and the American welfare state. Princeton: Princeton University Press.

Campbell, A. L. (2011). Policy feedbacks and the impact of policy designs on public opinion. Journal of Health Politics, Policy and Law, 36(6), 961-973.

Campbell, A. L. (2012). Policy makes mass politics. Annual Review of Political Science, 15(1), 333-351.

Capano, G., \& Howlett, M. (2020). The knowns and unknowns of policy instrument analysis: Policy tools and the current research agenda on policy mixes. SAGE Open, 10(1), 1-13.

Capoor, K., \& Ambrosi, P. (2009). State and trends of the carbon market 2009. Washington, DC: World Bank.

Cashore, B., \& Howlett, M. (2007). Punctuating which equilibrium? Understanding thermostatic policy dynamics in Pacific Northwest forestry. American Journal of Political Science, 51(3), 532-551.

Council, European. (2014). Presidency conclusions of the European Council-23/24 October 2014. Brussels: European Council.

Dagan, D., \& Teles, S. M. (2015). The social construction of policy feedback: Incarceration, conservatism, and ideological change. Studies in American Political Development, 29(02), 127-153.

Daugbjerg, C. (1997). Policy networks and agricultural policy reforms: Explaining deregulation in Sweden and re-regulation in the European Community. Governance, 10(2), 123-141.

Daugbjerg, C. (2003). Policy feedback and paradigm shift in EU agricultural policy: the effects of the MacSharry reform on future reform. Journal of European Public Policy, 10(3), 421-437.

de Bruyn, S., Schep, E., \& Cherif, S. (2016). Calculation of additional profits of sectors and firms from the EU ETS. Delft: CE Delft.

DG Environment, \& Ecofys (2006). Auctioning of $\mathrm{CO}_{2}$ emission allowances in the EU ETS: Report under the project 'Review of EU Emissions Trading Scheme'. Brussels: European Commission.

Dupuis, J., \& Biesbroek, R. (2013). Comparing apples and oranges: The dependent variable problem in comparing and evaluating climate change adaptation policies. Global Environmental Change, 23(6), 1476-1487.

Eckstein, H. (1975). Case study and theory in political science. In F. Greenstein \& N. Polsby (Eds.), Handbook of political science (pp. 79-138). Addison Wesle: Reading.

ENDS Report (2008). EU climate package is approved. Twickenham: Haymarket Media Group.

Eurelectric (2001). Union of the electricity industry-EURELECTRIC position paper on emissions trading. Brussels: Eurelectric.

European Commission (2001a). Proposal for a directive of the European parliament and of the council establishing a scheme for greenhouse gas emission allowance trading within the Community and amending Council Directive 96/61/EC. Brussels: European Commission.

European Commission (2001b). Green paper on greenhouse gas emissions trading within the European Union: Summary of submissions. Brussels: European Commission.

European Commission (2012). The state of the European carbon market in 2012. Brussels: European Commission.

European Commission (2013). Options for structural measures to strengthen the EU emissions trading system: Main outcomes of the public consultation. Brussels: European Commission. 
European Commission (2015). Impact assessment accompanying the document: Proposal for a directive of the European parliament and of the council amending directive 2003/87/EC to enhance cost-effective emission reductions and low-carbon investments. Brussels: European Commission.

European Commission (2017). Analysis of the use of auction revenues by the member states. Brussels: European Commission.

Green-Pedersen, C. (2004). The dependent variable problem within the study of welfare state retrenchment: Defining the problem and looking for solutions. Journal of Comparative Policy Analysis: Research and Practice, 6(1), 3-14.

Hacker, J. S. (1998). The historical logic of national health insurance: Structure and sequence in the development of British, Canadian, and US medical policy. Studies in American Political Development, 12(1), 57-130.

Haelg, L., Sewerin, S., \& Schmidt, T. S. (2020). The role of actors in the policy design process: Introducing design coalitions to explain policy output. Policy Sciences.

Hall, P. A. (1993). Policy paradigms, social learning, and the state: The case of economic policymaking in Britain. Comparative Politics, 25, 275-296.

Howlett, M., \& Cashore, B. (2009). The dependent variable problem in the study of policy change: Understanding policy change as a methodological problem. Journal of Comparative Policy Analysis, 11(1), 33-46.

Jacobs, A. M., \& Weaver, R. K. (2015). When policies undo themselves: Self-undermining feedback as a source of policy change. Governance, 28(4), 441-457.

Jenkins-Smith, H., Nohrstedt, D., Weible, C., \& Sabatier, P. A. (2014). The advocacy coalition framework: Foundations, evolution, and ongoing research. In P. A. Sabatier \& C. Weible (Eds.), Theories of the policy process (3rd ed.). Boulder, CO: Westview Press.

Jevnaker, T., \& Wettestad, J. (2017). Ratcheting up carbon trade: The politics of reforming EU emissions trading. Global Environmental Politics, 17(2), 105-124.

Jordan, A., \& Matt, E. (2014). Designing policies that intentionally stick: Policy feedback in a changing climate. Policy Sciences, 47(3), 227-247.

Jordan, A., \& Moore, B. (2020). Durable by design? Policy feedback in a changing climate. Cambridge: Cambridge University Press.

Koreh, M., Mandelkern, R., \& Shpaizman, I. (2019). A dynamic theoretical framework of gradual institutional changes. Public Administration, 97, 1-16.

Meckling, J. (2011). Carbon coalitions: Business, climate politics, and the rise of emissions trading. Cambridge: MIT Press.

Meckling, J. (2019). Governing renewables: Policy feedback in a global energy transition. Environment and Planning C: Politics and Space, 37(2), 317-338.

Mettler, S. (2002). Bringing the state back into civic engagement: Policy feedback effects of the GI Bill for World War II veterans. American Political Science Review, 96(2), 351-365.

Mettler, S., \& SoRelle, M. (2014). Policy feedback theory. In P. A. Sabatier \& C. M. Weible (Eds.), Theories of the policy process (3rd ed.). London: Taylor \& Francis.

Moore, B. (2018). The political effects of climate policy: Policy feedback from the European Union Emissions Trading System. Ph.D. thesis. University of East Anglia, Norwich, UK.

Müller, P., \& Slominski, P. (2013). Agree now-pay later: Escaping the joint decision trap in the evolution of the EU emission trading system. Journal of European Public Policy, 20(10), 1425-1442.

Oberlander, J., \& Weaver, R. K. (2015). Unraveling from within? The Affordable Care Act and selfundermining policy feedbacks. The Forum, 13(1), 37-62.

Patashnik, E. M. (2008). Reforms at risk: What happens after major policy changes are enacted. Princeton: Princeton University Press.

Phidd, R., \& Doern, B. (1992). Canadian public policy. Toronto: Methuen.

Pierson, P. (1993). When effect becomes cause: Policy feedback and political change. World Politics, 45(4), 595-628.

Pierson, P. (1994). Dismantling the welfare state? Reagan, Thatcher and the politics of retrenchment. Cambridge: Cambridge University Press.

Pierson, P. (2000). Increasing returns, path dependence, and the study of politics. American Political Science Review, 94(2), 251-267.

Pierson, P. (2004). Politics in time: History, institutions, and social analysis. Princeton: Princeton University Press.

Point Carbon (2018). Carbon market monitor: Decreased uncertainty as carbon market reforms conclude. Oslo: Point Carbon.

Polish Electricity Association (2013). Response of the Polish Electricity Association (PKEE) concerning a public consultation on the EC Green Paper-A 2030 framework for climate and energy policies. 
Sandbag (2019). Carbon price viewer. Retrieved May 15, 2019 from https://sandbag.org.uk/carbon-price -viewer.

Schaffrin, A., Sewerin, S., \& Seubert, S. (2015). Toward a comparative measure of climate policy output. Policy Studies Journal, 43(2), 257-282.

Schattschneider, E. E. (1935). Politics, pressures and the tariff: A study of free private enterprise in pressure politics, as shown in the 1929-1930 revision of the tariff. New York: Prentice-Hall.

Sewerin, S., Béland, D., \& Cashore, B. (2020). Designing policy for the long term: Integrating agency and policy feedback for uncovering durable pathways of change. Policy Sciences.

Sijm, J., Neuhoff, K., \& Chen, Y. (2006). $\mathrm{CO}_{2}$ cost pass-through and windfall profits in the power sector. Climate Policy, 6(1), 49-72.

Simons, A., \& Voß, J.-P. (2018). The concept of instrument constituencies: Accounting for dynamics and practices of knowing governance. Policy and Society, 37(1), 14-35.

Skjærseth, J. B. (2018). Implementing EU climate and energy policies in Poland: Policy feedback and reform. Environmental Politics, 27(3), 498-518.

Skjærseth, J. B., \& Wettestad, J. (2008). EU emissions trading: Initiation, decision-making and implementation. Farnham: Ashgate.

Skjærseth, J. B., \& Wettestad, J. (2010). Fixing the EU emissions trading system? Understanding the post2012 changes. Global Environmental Politics, 10(4), 101-123.

Skocpol, T. (1992). Protecting soldiers and mothers: The political origins of social policy in the United States. Cambridge, MA: Belknap Press.

Skogstad, G. (2017). Policy feedback and self-reinforcing and self-undermining processes in EU biofuels policy. Journal of European Public Policy, 24(1), 21-41.

Tietenberg, T. H. (2006). Emissions trading: Principles and practice. Washington, DC: Resources for the Future.

Voß, J.-P., \& Simons, A. (2014). Instrument constituencies and the supply side of policy innovation: The social life of emissions trading. Environmental Politics, 23(5), 735-754.

Weaver, R. K. (2010). Paths and forks or chutes and ladders? Negative feedbacks and policy regime change. Journal of Public Policy, 30(2), 137-162.

Wettestad, J. (2009). EU energy-intensive industries and emission trading: Losers becoming winners? Environmental Policy and Governance, 19(5), 309-320.

Wettestad, J., \& Jevnaker, T. (2016). Rescuing EU emissions trading: The climate policy flagship. London: Palgrave Macmillan.

Wettestad, J., \& Jevnaker, T. (2019). Smokescreen politics? Ratcheting up EU emissions trading in 2017. Review of Policy Research, 36(5), 635-659.

Publisher's Note Springer Nature remains neutral with regard to jurisdictional claims in published maps and institutional affiliations. 